\title{
Use of energy drinks and their impact on the body based on the view of student population
}

\author{
${ }^{1}$ Andjelka M. Milovic, ${ }^{2}$ Mirjana B. Pesic, \\ ${ }^{2}$ Aleksandar Z. Kostic, \\ ${ }^{2 *}$ Sladjana P. Stanojevic \\ ${ }^{1}$ Il year student of the bachelor studies of the \\ Faculty of Agriculture, University of Belgrade, \\ Module: Technology of conservation and boiling; \\ Institute of Food Technology and Biochemistry \\ ${ }^{2}$ Faculty of Agriculture, University of Belgrade, \\ Institute of Food Technology and Biochemistry \\ Corresponding author: \\ Sladjana Stanojevic, PhD \\ Faculty of Agriculture, University of Belgrade, \\ Institute of Food Technology and Biochemistry, \\ Nemanjina 6, 11080 Zemun, P.O. Box 14, Serbia \\ Tel/Fax: +381 112199711 \\ E-mail address: sladjas@agrif.bg.ac.rs
}

\begin{abstract}
In recent years, studies have often been devoted to the frequent on frequency, motives and consequences of consuming energy drinks by the student population at universities. These studies have been common in many countries. The aim of this study was to identify the patterns of energy drink consumption among college students of the Serbian University of Belgrade and to understand the attitudes, motives and consequences of consuming these beverages. The result of this study indicates that energy drink consumption is a common practice among Serbian university students $(72.0 \%$ use energy drinks and $1.1 \%$ consume them regularly). Out of the total number of surveyed students $12.9 \%$ consumed energy drinks with alcohol. The most frequent negative effects in students who had used energy drinks were: weight gain (24.2\%), headaches (2.6\%), thirst (18.9\%) and hunger (11.6\%). Many of the students surveyed (62.0\%) cited that their main motive for using energy drinks was improving their academic capabilities, commonly used as a way to study longer and improve mental focus. But, 10.5\% of the surveyed students felt the effect of increased concentration after using energy drinks. This indicated the students' confusion and disagreement between their motives for using energy drinks and the effects achieved. A large number of surveyed students (85.3\%) did not
\end{abstract} check the composition of energy drinks before consumption. The results show that students need education in this regard. This research is part of a study called "Attitudes and Behavior of Students in relation to Food and Nutrition" and is a form of preventive action to combat the widespread use of energy drinks in the student population.

Key words: energy drinks; college students; motivation; effects; nutrition; anonymous survey.

\section{INTRODUCTION}

There is no agreed definition in the regulatory framework for the products referred to as "stimulant" or "energy" drinks. These drinks are usually defined as "beverages, which typically contain caffeine, taurine and vitamin(s), and may contain an energy source (e.g. carbohydrate), and/or other substance(s), marketed for the specific purpose of providing real or perceived enhanced physiological and/or performance effects" [1]. Energy drinks are one of the most commonly used functional beverages among commercially available non-alcoholic beverages [2]. High concentrations of caffeine with a distinctive taste and color, as well as attractive packaging and advanced marketing, have contributed to making energy drinks a mass-produced product across the globe. These drinks often provide a sense of refreshment, good taste and high energy. Energy drinks are often consumed by athletes, adolescents and college students in large quantities [2]. In most countries, minors are not prohibited from consuming them [3], and there are no specific prohibitions in this regard in Serbia either.

The content of energy drinks varies by brand and type, and it may include: water, caffeine, taurine, glucuronolactone, B-group vitamins, glucose, sucrose, inositol, guarana essence, ginseng, gingko biloba and carnitine $[1,4-6]$. Research indicates that the synergistic effect on the body of all energy drink constituents is greater than the effect of each one individually $[7,8]$. There are conflicting opinions as to whether the 
effect of the constituents of energy drinks is desirable to the body or not. Namely, some studies point out that, thanks to these ingredients, energy drinks improve physical and mental stamina, concentration, ability to perceive, as well as the level of caution and vigilance, and contribute to a faster recovery from demanding physical activities [8,9]. On the other hand, it highlights possible toxicity and concern for potentially serious adverse effects associated with the use of energy drinks, such as insomnia, gastrointestinal disorders, chest pain, palpitations, seizures, headaches, sexual dysfunctions and feelings of "distress" $[10,11]$. In the last decade, many publications have addressed the study of caffeine and sugar intake as the two biggest risks when consuming energy drinks. Energy drinks typically contain large amounts of caffeine [1]. Caffeine is found in almost all commercially available energy drinks at a concentration of about $11-90 \mu \mathrm{g} / \mathrm{ml}$ [12]. Caffeine is a methylxanthine class alkaloid and is naturally present in many plants (leaves, seeds, fruits) [13], and can be found in chocolate and dietary supplements [1]. The daily intake of caffeine, which is of no concern as for the occurrence of adverse effects, varies from individual to individual, but for most people it is up to $200 \mathrm{mg} /$ day [14]. Caffeine is a stimulant and in large quantities it can cause palpitations (strong throbbing) of the heart, as well as nervousness, irritability and insomnia [14]. Heckman et al [15] point out that caffeine intake can be harmful in pregnancy (it can increase the risk of fetal damage and decrease fertility). In addition, it can lead to liver and kidney problems [2]. However, there are conflicting opinions as to whether caffeine increases the risk of cardiovascular disease, as well as the risk of diabetes type 2 [15]. On the other hand, it has been proven that caffeine increases resting energy consumption (by promoting fat lipolysis), increases endurance and improves performance, increases "mental energy" and directly supports the central nervous system [16], increases cognitive brain functioning [17], delays fatigue [18], increases energy efficiency, and reduces the level of effort during training [19]. In addition, it has been proven that caffeine plays a role in the prevention of sunlight-induced skin cancer [20], as well as in helping people lose weight [21].

Many studies highlight the sugar content of energy drinks, where obesity and the risk of type 2 diabetes are the biggest problems [22]. On average, energy drinks contain $10 \mathrm{~g}$ of sugar/100 $\mathrm{ml}$ [2].

The combination of energy drinks with alcohol is a new "trend" that has been spreading rapidly among adolescents and college students in recent years [23-26]. Studies with American (26\%) [27] and Italian (48.4\%) [28] students show a high prevalence of consuming energy drinks with alcohol. This drink combi- nation reduces the feeling of drowsiness and increases the feeling of pleasure. But, this combination of drinking can also cause serious problems, such as body dehydration that is caused by alcohol consumption and is enhanced by the effects of caffeine [23]. Then, the dehydrating effect of caffeine prevents the body's ability to metabolize ethanol. It increases alcohol toxicity as well as adrenaline release [29].

Considering both the frequency of the consumption of energy drinks in the student population (for example, 54\% of US students) [27] and the large number of disorders resulting from such behavior (in terms of metabolic and health problems, as well as unacceptable social behavior and psychiatric problems), in recent years research has often been done on the frequency and consequences of consuming energy drinks in the student population [6,23-30]. In the literature available to us, there is no data on the frequency, motives and consequences of consumption of energy drinks at the faculties of the Serbian University of Belgrade. The aim of this study was (1) to identify patterns of energy drink consumption among college students of the Institute of Food Technology and Biochemistry, on Faculty of Agriculture, University of Belgrade and (2) to understand the attitudes, motives and consequences of consuming these beverages.

\section{PARTICIPANTS AND METHODS}

The study was conducted using anonymous questionnaires. The survey was voluntarily done by 264 students of the bachelor studies at the Institute of Food Technology and Biochemistry, Faculty of Agriculture, University of Belgrade (174 female and 90 male subjects). The surveyed students were selected randomly; all students had an equal chance of being selected for the sample. This study was conducted according to the guidelines laid in the General Regulation on Data Protection of the European Union. This research is a part of a broader study titled "Attitudes and behavior of students in relation to food and nutrition" conducted among students of the Faculty of Agriculture, University of Belgrade, on the subject of "Food Biochemistry".

Descriptive statistics methods were used to process and analyze the data. Version 8.0 software (StatSoft Co., Tulsa, Oklahoma, USA) was used for statistical processing of the results. 


\section{RESULTS}

The study sample included 264 students of the second year of bachelor studies, between the ages of 20 and 23 (the average age was $21.78 \pm 1.3$ ) and all were of Serbian nationality. The sample was composed of 174 females (65.9\%) and 90 males (34.1\%). Most students are housed in a dorm (86.8\%) and most respondents usually study by day ( $81.8 \%$ ). $20.5 \%$ of the respondents are athletes and actively involved in sports. $11.4 \%$ of the students used cigarettes and $18.9 \%$ alcohol, $72.0 \%$ of the surveyed students consumed energy drinks (Table 1).

Table 1. Participants' socio-demographic characteristics and individual habits of energy drink users $(\mathrm{N}=264)$.

\begin{tabular}{|c|c|c|}
\hline Characteristics & $\mathrm{n}$ & $\%$ \\
\hline \multicolumn{3}{|l|}{ Gender } \\
\hline Male & 90 & 34.1 \\
\hline Female & 174 & 65.9 \\
\hline \multicolumn{3}{|c|}{ Age groups (average age - 21.78 \pm 1.3 ) } \\
\hline $21-23$ & 264 & 100 \\
\hline \multicolumn{3}{|l|}{ Physical activity status } \\
\hline athlete & 54 & 20.5 \\
\hline not athlete & 210 & 79.5 \\
\hline \multicolumn{3}{|l|}{ Class status } \\
\hline $2^{\text {nd }}$ year & 264 & 100 \\
\hline \multicolumn{3}{|l|}{ Usual study time } \\
\hline Day & 216 & 81.8 \\
\hline Night & 48 & 18.2 \\
\hline \multicolumn{3}{|l|}{ Nationality } \\
\hline Serbian & 264 & 100 \\
\hline \multicolumn{3}{|l|}{ Consuming energy drinks } \\
\hline No & 74 & 28.0 \\
\hline Yes & 190 & 72.0 \\
\hline \multicolumn{3}{|l|}{ Accommodation } \\
\hline Dorm & 229 & 86.8 \\
\hline At home with family & 32 & 12.1 \\
\hline Living with a friend & 3 & 1.1 \\
\hline \multicolumn{3}{|l|}{ Cigarette use } \\
\hline No & 202 & 76.5 \\
\hline Yes & 30 & 11.4 \\
\hline Quit & 32 & 12.1 \\
\hline \multicolumn{3}{|l|}{ Alcohol use } \\
\hline No & 205 & 77.7 \\
\hline Yes & 50 & 18.9 \\
\hline Quit & 9 & 3.4 \\
\hline
\end{tabular}

A large number of students (89.0\%) responded that they most often drink water when they are thirsty (Figure 1). While $28.0 \%$ of students have not consumed

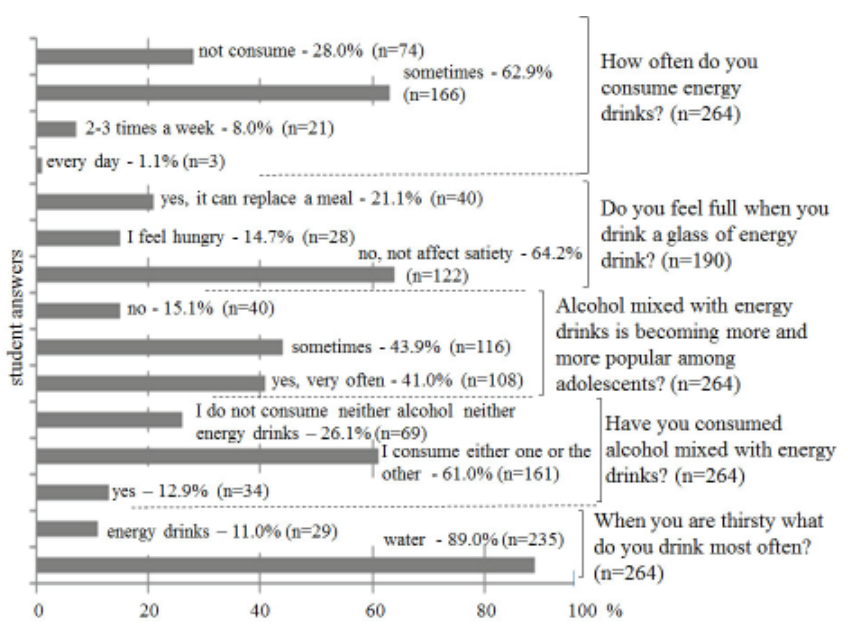

Figure 1. Results of the interviewed students' answers to questions related to their energy drink habits.

energy drinks, $62.9 \%$ consume them occasionally, 8.0\% 2-3 times a week, and only $1.1 \%$ consume energy drinks every day. Their motives for consuming energy drinks were different. Most of the respondents linked consuming energy drinks with obligations at the faculty. So, their basic motives for consuming energy drinks were to improve their concentration in class $(35.8 \%)$ and spend a longer period of time learning (15.1\%) (Table 2). A significant number of students responded that their motive for consuming energy drinks was to improve their mental focus (11.1\%) and athletic performance $(10.6 \%)$, as well as endurance with longer periods of exercise (10.6\%). Few students cited a reason for using energy drinks for better sleep (2.1\%), to have less need for sleep (1.1\%), a good feeling overall (1.6\%), feeling less restless (1.6\%), or long-term driving (3.2\%) (Table 2). The students surveyed most often consume Guarana $(31.1 \%)$ from the array of energy drinks offered in the Serbian market (Figure 2).

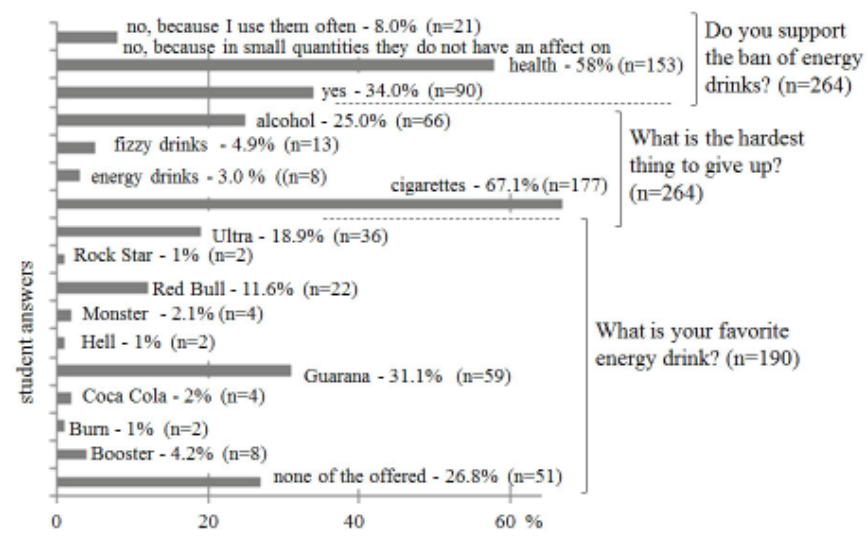

Figure 2. Results of the interviewed students' answers to questions related to the consumption of certain energy drink brands and their views on the consumption of energy drinks. 
Table 2. The most common reasons/motivations for consuming/not consuming energy drinks.

\begin{tabular}{lll}
\hline \multirow{2}{*}{ Offered reasons } & \multicolumn{2}{l}{$\begin{array}{l}\text { Consuming energy } \\
(\mathrm{N}=190)^{*}\end{array}$} \\
\cline { 2 - 3 } & $\mathrm{n}$ & $\%$ \\
\hline Concentrate in class & 68 & 35.8 \\
Study longer & 30 & 15.1 \\
Improve mental focus & 21 & 11.1 \\
Feel good & 3 & 1.6 \\
Feeling less restless & 3 & 1.6 \\
Less need for sleep & 2 & 1.1 \\
Better sleep & 4 & 2.1 \\
Needed more energy & 6 & 3.2 \\
Exercise longer & 22 & 11.6 \\
Improve athletic performance & 22 & 11.6 \\
Drive for a long period of time & 6 & 3.2 \\
Prolong the effects of alcohol & - & - \\
Lose weight & - & - \\
Being more involved in circle of & 3 & 1.6 \\
friends & - & - \\
Addicted & - & - \\
Curiosity & & \\
\hline
\end{tabular}

Not consuming energy drinks

\begin{tabular}{lll} 
Motivation & \multicolumn{2}{l}{$(\mathrm{N}=74)^{* *}$} \\
\cline { 2 - 3 } & $\mathrm{n}$ & $\%$ \\
\hline Can be harmful to health & 40 & 54.1 \\
Can create dependency & 9 & 12.1 \\
Can lead to obesity & 7 & 9.5 \\
Can lead to poor sleep & 6 & 8.1 \\
Expensive & 10 & 13.5 \\
No interest & 2 & 2.7 \\
\hline
\end{tabular}

*Only responses from students consuming energy drinks were considered.

**Only responses from students who do not consume energy drinks were considered.

The desired effects felt by students after consuming energy drinks are feeling more energetic (34.2\%) and happier (20.5\%), as well as less sleepy $(13.1 \%)$ and having increased concentration (10.5\%). In addition, fewer students responded that after using energy drinks, they felt more endurance in training (4.7\%) and over a longer driving period (5.8\%). Desired effects were not felt by $11.1 \%$ of students (Table 3 ).
Table 3. The most common effects among students who use energy drinks $(\mathrm{N}=190)^{*}$.

\begin{tabular}{|c|c|c|}
\hline \multirow{2}{*}{ Effects } & \multicolumn{2}{|c|}{ Consuming energy drinks } \\
\hline & $\mathrm{n}$ & $\%$ \\
\hline \multicolumn{3}{|l|}{ Desired effects } \\
\hline More energetic & 65 & 34.2 \\
\hline Less sleepy & 25 & 13.1 \\
\hline More happy & 39 & 20.5 \\
\hline Increased concentration & 20 & 10.5 \\
\hline Higher endurance in training & 9 & 4.7 \\
\hline Longer driving period & 11 & 5.8 \\
\hline Not felt desired effect & 21 & 11.1 \\
\hline \multicolumn{3}{|l|}{ Unwanted effects } \\
\hline Palpitations & 9 & 4.7 \\
\hline Sleeplessness & 7 & 3.7 \\
\hline Headache & 5 & 2.6 \\
\hline Thirst & 36 & 18.9 \\
\hline Hunger & 22 & 11.6 \\
\hline Vertigo & 11 & 5.8 \\
\hline Weight gain & 46 & 24.2 \\
\hline Not felt unwanted effect & 54 & 28.4 \\
\hline
\end{tabular}

*Only responses from students consuming energy drinks were considered.

A large number of respondents (84.9\%) believe that energy drinks mixed with alcohol are popular among adolescents (very often $-41.0 \%$ and sometimes 43.9\%). The level of students using energy drinks and mixing these with alcohol was $12.9 \%$, while $61.0 \%$ of respondents replied that they consumed either one or the other (Figure 1). Students find it very difficult to quit cigarettes (67.1\%), then alcohol (25.0\%), and then fizzy (4.9\%) and energy (3.0\%) drinks (Figure 2).

Among the reasons cited by those not using energy drinks were: fears they may be harmful to health (54.1\%), can create dependency $(12.1 \%)$, can lead to obesity $(9.5 \%)$, can lead to poor sleep $(8.1 \%)$, they considered the drinks expensive (13.5\%), or they just weren't interested (2.7\%) (Table 2).

A significant number of students (14.7\%) do not feel satiated after consuming an energy drink, while $21.1 \%$ think that an energy drink can replace their meal (Figure 1). Most of the students surveyed responded that energy drinks (83.0\%) have the most sugar compared to the other two answers offered: fruit juice (14.0\%) and alcohol drink (3.0\%). Almost all students (98.1\%) are aware that caffeine is contained in energy drinks, 
Milovic et al.: Use of energy drinks and their impact on the body based on the view of student..

and $33.0 \%$ said that $11-100 \mu \mathrm{g}$ of caffeine is in $1 \mathrm{ml}$ of energy drinks (Figure 3).

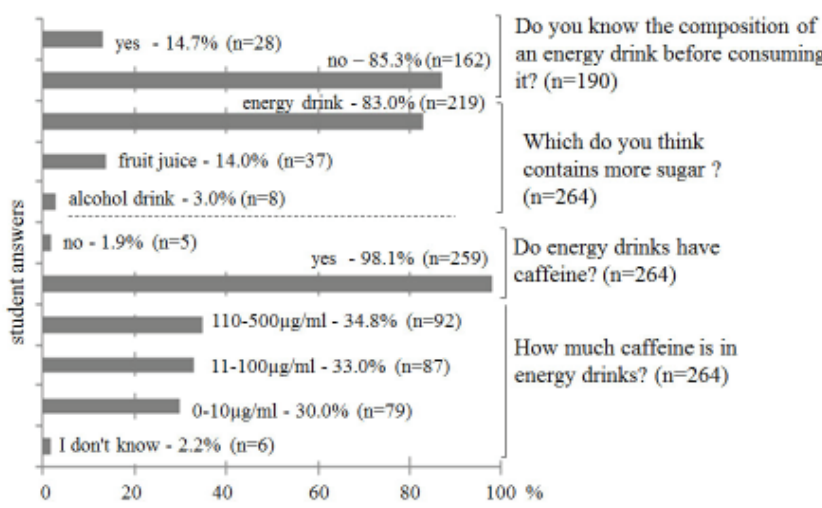

Figure 3. Results of the interviewed students' answers to questions related to their basic knowledge of the content of individual components in energy drinks.

The students answered to a group of questions that were related to possible side effects and the occurrence of metabolic problems. They considered that the overuse of energy drinks can lead to sterility (28.0\%), irregular heartbeat $(64.0 \%)$, hypertension $(20.1 \%)$, diabetes $(6.8 \%)$, obesity $(3.0 \%)$, tachycardia $(2.3 \%)$, insomnia $(2.3 \%)$ and disorders of the cardiovascular and nervous system (89.0\%). The students pointed out that the occurrence of most of these problems depends on the amount of energy drinks consumed, except for obesity, which a large number of students (73.1\%) thought appears regardless of the amount of energy drinks consumed (Figure 4). Students surveyed would not, in the vast majority $(66.0 \%)$, support the ban on the use of energy drinks, since they believe that they are not harmful to health in small quantities (58.0\%) (Figure 2).

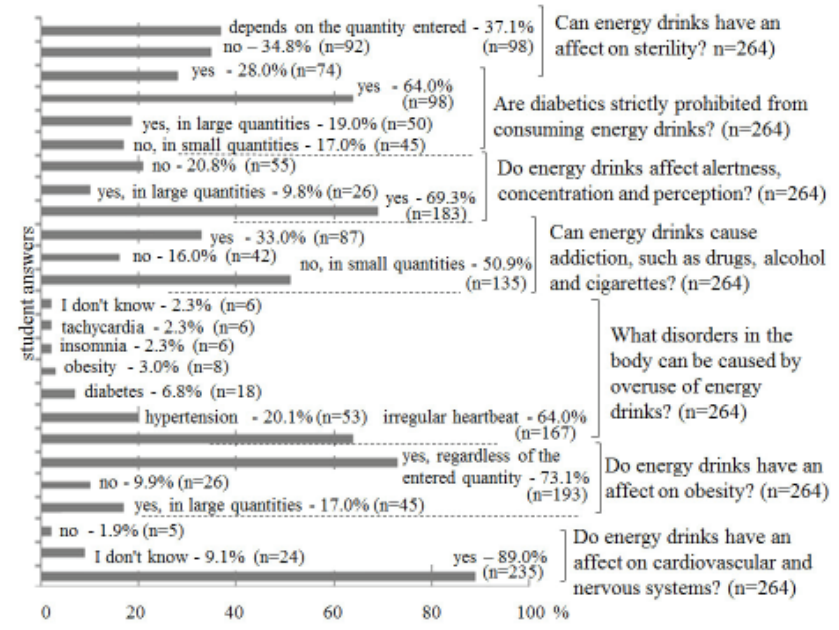

Figure 4. Results of the interviewed students' answers to questions related to their knowledge about the harmful effects of energy drinks on the body.

The most frequent negative effects found in students who had used energy drinks were: weight gain (24.2\%), thirst (18.9\%), hunger (11.6\%), vertigo (5.8\%), palpitations (4.7\%), sleeplessness (3.7\%) and headache
(2.6\%). Unwanted effects were not felt by $28.4 \%$ of students (Table 3 ).

\section{DISCUSSION}

Our study revealed that $72.0 \%$ of the Serbian surveyed students used energy drinks, while $1.1 \%$ used them regularly (every day). The results of this study indicate that energy drink consumption is a common practice among Serbian university students. Studies in other countries show less use of energy drinks by students. Namely, in a study of university students in Turkey, $46.5 \%$ used energy drinks at least once [30]. In another study of university students in the United States, 54\% were reported as having used energy drinks [27], or $56.9 \%$ college students in Italy [28]. However, Serbian students are less likely to drink energy drinks mixed with alcohol (13\%) than college students in other countries. Studies with American (26\%) [27] and Italian (48.4\%) [28] students show a greater consumption of energy drinks with alcohol.

For Serbian college students the motivations for their use of energy drinks were similar to that documented in studies from other countries. In the survey, the most commonly cited reason for using energy drinks was their desire to concentrate better in class, study longer, exercise longer and improve athletic performance and mental focus (Table 2). For example, Oglesby et al. [29] pointed out the reasons for using energy drinks by students from a private university in the southwestern United States. These reasons were: studying longer (34\%), concentrating when studying (32\%), concentrating in class (11.5\%) and improving mental focus (19.8\%). In his study, Bulut et al. [30] noted that most students at a university in Turkey cited an increase in physical performance (34.5\%) as a reason for using energy drinks. For most American students, the main reason for using energy drinks is feeling more energetic (57.0\%) [29]. This was not the most common reason for Serbian students (Table 2). But, most of the students surveyed just cited the feeling of having more energy as one of the effects of using energy drinks (Table 3). Nonetheless, the results of this study showed that for most students, the main reason for using energy drinks was to increase their learning ability. But, in fact, only 20 students of the 190 students felt the effects of increased concentration after using energy drinks (Table 3). Such results indicated the students' confusion and disagreement between their motives for using energy drinks and the effects achieved. This may explain the high level of experimentation with energy drinks and college students in recent years.

Although a large number of students thought that consuming energy drinks mixed with alcohol was a very common occurrence among university students, (Figure 1) in fact, this was done only by $12.9 \%$ of the 
total surveyed students. If this result is compared with research at universities in other countries, this is not a worrying percentage. Namely, studies with American (26\%) [27] and Italian (48.4\%) [28] students show a much high prevalence of consuming energy drinks mixed with alcohol. It is very important to be aware of the frequency of consumption of energy drinks and alcohol since literature data suggest that consumption of energy drinks mixed with alcohol is associated with smoking, illicit prescription use, and stimulant drug use (e.g. amphetamine) $[2,22,27,30]$.

A worrying result of this study may be the low level of student interest in the composition and content of individual components in energy drinks. Namely, less than 30 students from 190 students became interested in the composition of energy drinks. A large number of students knew that caffeine was present in energy drinks, but only a third of respondents knew the exact range of the usual caffeine content $(11-90 \mu \mathrm{g} / \mathrm{ml}$; [12]) in energy drinks (Figure 3). This result indicates that students need education in this regard.

Students have shown knowledge of the unwanted metabolic effects that can occur as a result of using energy drinks. That is what can be worrying for a lot of students who use energy drinks despite being aware of the possible occurrence of numerous health problems. Some of these unwanted effects were felt, such as: palpitations, sleeplessness, headaches, thirst, hunger, vertigo and weight gain. Most of these side effects have also been reported by students from other countries [30]. In this study, the majority of students reported weight gain as a side effect of consuming energy drinks. This is in line with the feeling of hunger after using energy drinks. Given the high sugar content of energy drinks [2,22], such results were expected.

\section{CONCLUSIONS}

Energy drink consumption is a common practice among Serbian students. Many college students claimed to use energy drinks as a way of improving their academic capabilities, commonly as a way to study longer and improve athletic performance, but a small number of surveyed students achieved these effects. Such results indicated the students' confusion and disagreement between their motives for using energy drinks and the effects achieved. The level of student interest in the composition and content of individual components in energy drinks is low. A large number of students thought that consuming energy drinks mixed with alcohol was a trend among university students. This kind of thinking should suggest caution, because it can lead to a significant increase in the number of students consuming energy drinks with alcohol. After consuming energy drinks, students felt the usual unwanted effects, and particularly empha- sized weight gain. The results of this study show that students need education in this regard. Generally, this research may help us better understand patterns of energy drinks consumption in college students' population.

\section{ACKNOWLEDGMENTS}

The authors thank the students of the second year of the bachelor studies at the Institute of Food Technology and Biochemistry, Faculty of Agriculture, University of Belgrade, for their participation in this research. This publication was supported by the Ministry of Education, Science and Technological Development of the Republic of Serbia (Grants no. 451-03-68/202014/200116). Ministry of Education, Science and Technological Development of the Republic of Serbia had no role in the design, analysis or writing of this article.

\section{REFERENCES}

1. Food Safety Promotion Board [Internet]. A review of the health effects of stimulant drinks; 2002. [cited 2020 April 14]. Available from: http://www.safefoodonline. com/safefood/Uploads/health_effects.pdf.

2. Rácz A, Héberger K, Fodor M. Quantitative determination and classification of energy drinks using near-infrared spectroscopy. Anal Bioanal Chem. 2016; 408(23):6403-11.

3. Reissig CJ, Strain EC, Griffiths RR. Caffeinated energy drinks - A growing problem. Review. Drug Alcohol Depend. 2009;99(1-3):1-10.

4. Ballard LS, Wellborn-Kim JJ, Clauson AK. Effects of commercial energy drink consumption on athletic performance and body composition. Phys Sportsmed. 2010;38(1):107-17.

5. Peacock A, Martin FH, Carr A. Energy drink ingredients. Contribution of caffeine and taurine to performance outcomes. Appetite. 2013;64:1-4.

6. Spierer KD, Blanding N, Santella A. Energy drink consumption and associated health behaviors among university students in an urban setting. J Community Health. 2014;39(1):132-138.

7. Marczinski C A, Fillmore MT, Bardgett M E, Howard MA. Effect of energy drinks mixed with alcohol on behavioral control. Risks for college students consuming trendy cocktails. Alcohol Clin Exp Res. 2011;35(7):1282-1292.

8. Scholey $A B$, Kennedy DO. Cognitive and physiological effects of an "energy drink". An evaluation of the whole drink and of glucose, caffeine and herbal flavouring fractions. Psychopharmacology (Berl). 2004;176(34):320-330.

9. Alford $\mathrm{C}, \mathrm{Cox} \mathrm{H}$, Wescott R. The effects of red bull energy drink on human performance and mood. Amino Acids. 2001;21(2):139-50.

10. Seifert MS, Schaechter LJ, Hershorin RE, Lipshultz ES. Health effects of energy drinks on children, adolescents, and young adults. Pediatrics. 2011;127(3):511-528.

11. Nordt SP, Vilke MG, Clark FR, Cantrell FL, Chan CT, Galinato $M$, et al. Energy drink use and adverse effects 
among emergency department patients. J Community Health. 2012;37(5):976-981.

12. Shar Z, Shoaib H, Anwar N, Zubair M, Hussain A, Khan K. Spectrophotometric determination of caffeine in selected pakistani beverages. J Food Processing \& Beverages. 2017;5(1):1-4.

13. Reinhard M. Evaluation of xanthine derivatives in chocolate - nutritional and chemical aspects. Z Lebensm Unters Forsch. 1997;205(3):175-84.

14. EFSA. Panel on dietetic products, nutrition and allergies (NDA). Scientific opinion on the safety of caffeine. EFSA Journal 2015;13(5):4102-4222.

15. Heckman MA, Weil J, Gonzalez de Mejia E. Caffeine (1,3,7-trimethylxanthine) in foods: a comprehensive review on consumption, functionality, safety, and regulatory matters. J Food Sci. 2010;75(3):77-87.

16. Glade JM. Caffeine - Not just a stimulant. Nutrition. 2010;26(10):932-38.

17. Koppelstaetter F, Poeppel TD, Siedentopf CM, Ischebeck $M$, Verius I, Haala FM, et al. Does caffeine modulate verbal working memory processes? An fMRI study. Neuroimage. 2008;39(1):492-9.

18. Walton C, Kalmar JM, Cafarelli E. Effect of caffeine on self-sustained firing in human motor units. J Physiol. 2002;545(2):671-9.

19. McClaran SR, Wetter TJ. Low doses of caffeine reduce heart rate during submaximal cycle ergometry. J Int Soc Sport Nutr. 2007;4:11-20.

20. Kerzendorfer C, O'Driscol M. UVB and caffeine: inhibiting the DNA damage response to protect against the adverse effect $s$ of UVB. J Invest Dermatol. 2009;129(7):1611-3.

21. Ballard TLP, Halaweish FT, Stevermer CL, Agrawal P, Vukovich MD. Naringin does not alter caffeine pharmacokinetics, energy expenditure, or cardiovascular haemo- dynamics in humans following caffeine consumption. Clin Exp Pharmacol Physiol. 2006;33(4):310-314.

22. Malik VS, Schulze MB, Hu FB. Intake of sugar-sweetened beverages and weight gain: a systematic review. Am J Clin Nutr. 2006;84(2):274-88.

23. Ferreira SE, de Mello MT, Pompéia $S$, de Souza-Formigoni MLO. Effects of energy drink ingestion on alcohol intoxication. Alcohol Clin Exp Res. 2006;30(4):598-605.

24. Malinauskas BM, Aeby VG, Overton RF, Carpenter-Aeby T, Barber-Heidal K. A survey of energy drink consumption patterns among college students. Nutr J. 2007;6:3542.

25. Ilie G, Boak A, Mann RE, Adlaf ME, Hamilton H, Asbridge $M$, et al. Energy drinks, alcohol, sports and traumatic brain injuries among adolescents. PLoS One. 2015;10(9):e0135860.

26. Patrick EM, Macuada C, Maggs LJ. Who uses alcohol mixed with energy drinks? Characteristics of college student users. J Am Coll Health. 2016;64(1):74-9.

27. Miller K. Wired: energy drinks, jock identity, masculine norms, and risk taking. J Am Coll Health. 2008;56(5):48189.

28. Oteri A, Salvo F, Caputi AP, Calapai G. Intake of energy drinks in association with alcoholic beverages in a cohort of students of the school of medicine of the university of Messina. Alcohol Clin Exp Res. 2007;31(10):167780.

29. Oglesby WL, Amrani AK, Wynveen JC, Gallucci RA. Do energy drink consumers study more? J Community Health. 2018;43(1):48-54.

30. Bulut B, Beyhun EN, Topbas M, Can G. Energy drink use in university students and associated factors. J Community Health. 2014;39(5):1004-11.

\section{Stavovi studentske populacije o upotrebi energetskih napitaka i njihovom uticaju na organizam}

\author{
Andjelka M. Milovic, Mirjana B. Pesic, \\ Aleksandar Z. Kostic, Sladjana P. Stanojevic \\ Poljoprivredni fakultet, Univerzitet u Beogradu, Institut \\ za prehrambenu tehnologiju i biohemiju, Nemanjina 6, \\ 11080 Zemun, Srbija
}

\begin{abstract}
Kratak sadržaj
Poslednjih godina studije su često posvećene učestalosti, motivima i posledicama konzumiranja energetskih pića od strane studentske populacije. Ove studije su uobičajene u mnogim zemljama. Cilj ove studije bio je da identifikuje obrasce potrošnje energetskih pića među studentima Univerziteta u Beogradu i da objasni stavove, motive i posledice konzumiranja ovih pica. Rezultat ove studije ukazuje na to da je potrošnja energetskih pića
\end{abstract} uobičajena praksa među srpskim studentima (72.0\% koristi energetska pića, a 1.1\% ih redovno konzumira). Od ukupnog broja anketiranih studenata 12.9\% je konzumiralo energetska pića sa alkoholom. Najčešći negativni efekti kod studenata koji su koristili energetska pića bili su: debljanje (24.2\%), glavobolja (2.6\%), žeđ (18.9\%) i glad (11.6\%). Mnogi anketirani studenti (62.0\%) naveli su da je glavni motiv za korišćenje energetskih pića poboljšanje njihovih akademskih sposobnosti, odnosno, kao podstrek za duže učenje i poboljšanje mentalnog fokusa. Ali, samo $10.5 \%$ anketiranih studenata osetilo je efekat povećane koncentracije nakon upotrebe energetskih napitaka. Ovo je ukazalo na zbunjenost i neslaganje između motiva studenata za korišcenje energetskih pića i postignutih efekata. Veliki broj anketiranih učenika (85.3\%), nije proveravao sastav energetskih napitaka pre konzumiranja. Rezultati pokazuju da je učenicima potrebna edukacija u ovom pogledu. Ovo istraživanje je deo studije pod nazivom "Stavovi i ponašanje učenika u odnosu na hranu i ishranu" i predstavlja oblik preventivne akcije u borbi protiv široke upotrebe energetskih pića u studentskoj populaciji.

Ključne reči: energetska pica; studenti; motivacija; efekti; ishrana; anonimna anketa. 